\title{
Castor oil polyurethane containing silica nanoparticles as filling material of bone defect in rats ${ }^{1}$
}

\author{
Poliuretana de mamona contendo nanopartículas de sílica como \\ material de preenchimento de defeito ósseo em ratos
}

\begin{abstract}
Renato Silva NacerI, Rodrigo Ré Poppi ${ }^{\mathrm{II}}$, Paulo de Tarso Camilo de Carvalho ${ }^{\mathrm{III}}$, Baldomero Antonio Kato da Silva ${ }^{\mathrm{IV}}$, Alexandre

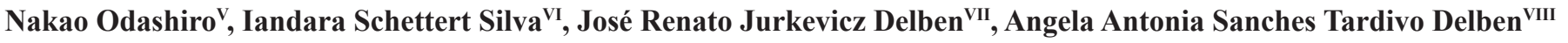

IFellow PhD degree, Health and Development in the West Central Region, UFMS, Campo Grande-MS, Brazil. Main author. Responsible for design, intellectual and scientific content of the study.

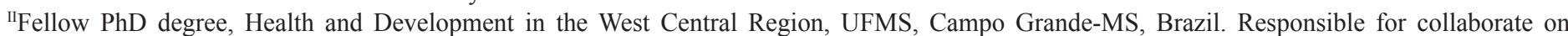
experimental procedures and manuscript writing.

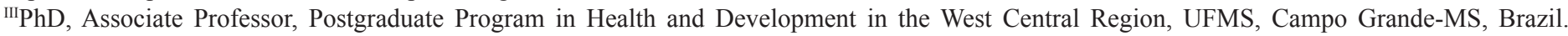
Conception, design, critical revision and manuscript writing.

${ }^{\mathrm{IV}}$ Fellow PhD degree, Health and Development in the West Central Region, UFMS. Associate Professor, University Anhanguera-Uniderp, Campo Grande-MS, Brazil. Acquisition of data, statistical analysis, manuscript writing and critical revision.

${ }^{\mathrm{v}} \mathrm{PhD}$, Associate Professor, Postgraduate Program in Health and Development in the West Central Region, UFMS, Campo Grande-MS, Brazil. Histopathologic examinations, acquisition of data and critical revision.

${ }^{\text {VI }} \mathrm{PhD}$, Associate Professor, Postgraduate Program in Health and Development in the West Central Region, UFMS, Campo Grande-MS, Brazil. Surgical procedures and critical revision.

VIIPhysics Department, UFMS, Campo Grande-MS, Brazil. Synthesis and production of biomaterials.

VIIIPhysics Department, UFMS, Campo Grande-MS, Brazil. Tutor. Responsible for conception and critical revision of the study.
\end{abstract}

\section{ABSTRACT}

PURPOSE: To evaluate the biologic behavior of the castor polymer containing silica nanoparticles as a bone substitute in diafisary defect.

METHODS: Twenty seven male rattus norvegicus albinus wistar lineage were submitted to bone defect filled with castor oil polymer. Three experimental groups had been formed with nine animals each: (1) castor oil polymer containing only calcium carbonate; (2) castor oil polymer with calcium carbonate and doped with 5\% of silica nanoparticles; (3) castor polymer with calcium carbonate doped with $10 \%$ of silica nanoparticles; 3 animals of each group were submitted to euthanasia 15, 30 and 60 days after experimental procedure, and their femurs were removed to histological evaluation.

RESULTS: there was bone growth in all the studied groups, with a greater tendency of growth in the group 1 . After 30 days all the groups presented similar results. After 60 days a greater amount of fibroblasts, osteoblasts, osteocytes and osteoclasts in group 3 was observed, with integrated activity of 3 kinds of cells involved in the bone activation-reabsorption-formation.

CONCLUSIONS: The castor polymer associated to the silica nanoparticles is biocompatible and allows osteoconduction. The presence of osteoprogenitors cells suggests silica osteoinduction capacity.

Key words: Biocompatible Materials. Bone Substitutes. Castor Oil. Rats.

\section{RESUMO}

OBJETIVO: Avaliar o comportamento biológico do polímero de mamona contendo nanopartículas de sílica como substituto ósseo.

MÉTODOS: Vinte e sete rattus norvergicus albinus, Wistar foram submetidos a defeito ósseo preenchido com polímero de mamona. Foram formados três grupos experimentais, com nove ratos cada: (1) Polímero com carbonato de cálcio; (2) Polímero com carbonato de cálcio dopado com 5\% de nanopartículas de sílica; (3) Polímero com carbonato de cálcio dopado com 10\% de nanopartículas de sílica; três animais de cada grupo foram submetidos à eutanásia 15, 30 e 60 dias após o procedimento experimental e os fêmures removidos e submetidos à avaliação histológica. 
RESULTADOS: Houve crescimento ósseo em todos os grupos estudados, com maior tendência de crescimento no grupo contendo polímero de mamona acrescido apenas por carbonato de cálcio. Aos 30 dias, todos os grupos apresentaram resultados semelhantes. Aos 60 dias, notou-se maior presença de fibroblastos, osteoblastos, osteócitos e osteoclastos no grupo 3, com persistência da atividade integrada dos três tipos de células envolvidas no processo de ativação-reabsorção-formação óssea.

CONCLUSÕES: O polímero de mamona associado com nanopartículas de sílica é biocompatível e permite a osteocondução. A presença de células osteoprogenitoras nos implantes contendo $10 \%$ de sílica indica sua capacidade osteoindutora.

Descritores: Materiais Biocompatíveis. Substitutos Ósseos. Óleo de Rícino. Ratos.

\section{Introduction}

The use of biopolymers as materials capable of promoting osteogenesis has considerably evolved in the last decades, mainly with the advent of the first class of polyurethanes, synthesized from vegetable fatty acid molecules, thus proving the superiority of the vegetable urethanes over the mineral derived resins ${ }^{1,2}$. Favorable aspects when implanted such as good processability, formulation flexibility, versatility in temperature of cure and exothermic peak control in gel-liquid transition, excellent structural properties and non releasing of steams and toxic radicals typify the castor polyurethane as an effective material in the bone repair process ${ }^{3-5}$. Among the main characteristics of the castor polymer, its internal porous architecture stands out ${ }^{6}$. The existence of porosity in the implants, their diameter, conformation and presence of intercommunication are important features which regulate cellular and vascular migration to the inner part of these implants allowing for the bone neoformation ${ }^{7,8}$.

The use of bioceramics comprises applications such as in metallic prosthesis coatings or in association with polymeric materials ${ }^{9}$. The bioactive ceramics stand out as biocompatible materials used as bone substitutes, due to their capacity of beeing produced in large quantities with control of physical and chemical parameters such as purity, porosity, superficial area and grains $\operatorname{size}^{10}$.

Mechanisms involved in the formation process of the hydroxyapatite layer in materials exposed to different physiological fluids are still controversial. Silica $\left(\mathrm{SiO}_{2}\right)$ presents chemical stability, transparency to visible light and bioinert/biocompatible properties which allow for its application as load in composed resins ${ }^{11,12}$. However there is a lack of information about the role of nanoparticled bioceramics in the polyurethane behaviour as far as osteogenesis is concerned.

Therefore, the aim of this study was to evaluate the behavior of the castor polymer in association with silica nanoparticles as material for bone defect filling in rats, based on the preparation of a new class of materials structurally similar to living tissues (polymer-ceramics nanocomposites) for medical and dental application

\section{Methods}

All the experimental procedures were analyzed and approved by the Ethic Commission in the Use of Animals/UFMS with protocol number 141/2007.

In the polymer preparation we used pre-polymer, poliol and calcium carbonate from Biomecânica, in the weight rate 1.0:0.9:1.0, as recommended by the fabricant.

\section{Sample characteristics and animal care}

Twenty-seven rats males adults (Rattus norvegicus Albinus) WISTAR, with weight varying between 230 and 350 grams, coming from the central vivarium of the University for Development of the State and the Pantanal Region - UNIDERP, Campo Grande, MS.

The animals were confined in cages of $0.15 \mathrm{~m}^{2}$, and kept in photoperiod of 12 hours, temperature and humidity maintained by air conditioning $\left(18\right.$ to $20{ }^{\circ} \mathrm{C}$ ), minimal noise, solid race and water ad libitum, being under observation for a period of two days before use in experiment.

\section{Animal group formation}

The animals were randomly divided into 3 distinct experimental groups associated with the filling material, G1 (reference) - castor oil polymer containing only calcium carbonate; G2- castor oil polymer with calcium carbonate and doped with 5\% of silica nanoparticles; G3- castor polymer with calcium carbonate doped with $10 \%$ of silica nanoparticles. Each group was divided into three subgroups, with 3 animals each, according to the day of euthanasia in the postoperative period set in 15,30 and 60 days.

\section{Surgical procedure}

The animals were anesthetized with intraperithonial 
solution injection of of $2 \%$ Xylasin Chloridrate in association with $5 \%$ Ketamine Chloridrate at $1: 2$ proportion in $0.10-0.15 \mathrm{ml} / 100 \mathrm{~g}$ body weight doses.

After the incision, the femoral diaphysis was spotted and a $2.00 \mathrm{~mm}$ diameter bone defect was produced using a spherical diamond tipped drill bit number 1016 (KG Sorensen) attached to a DREMEL ${ }^{\circledR} 300$ Series drilling machine at 5.000 RPM under constant irrigation with physiologic serum, drilling the bone cortical as far as the medullary canal.

\section{Filling material}

For the filling of the produced bone defect three different formulations of the castor polymer blocks $(2.00 \mathrm{~mm}$ diameter by $1.00 \mathrm{~mm}$ thick) were used: castor polymer (group 1); castor polymer containing 5\% silica nanoparticles, in weitgh (group 2); and castor polymer containing $10 \%$ silica nanoparticles, in weitgh (group 3).

\section{Euthanasia}

After the 15, 30 and 60-day observation periods, the animals were submitted to euthanasia with intraperithoneal infusion of lethal dose of Ketamine chloridrate and sodium Thiopental dissolved in sterile solution of sodium chloride saline solution at $0.9 \%$ in concentration of $100 \mathrm{mg} / \mathrm{ml}$.

\section{Sample preparation}

For the histological observation the obtained parts were immersed into a decalcifying Ethylene Diamyn Tetra Acetate (EDTA) solution, washed with running water, submitted to dehydration in ethylic alcohol at different concentrations, diafanization in xylol p.a. and inclusion in histological paraffin.

After the inclusions in paraffin, the blocks were submitted to sagital $5 \mu \mathrm{m}$ thick cuts and stained with Hematoxilyn and Eosin. Each field's image was obtained from a BX41 Olympus ${ }^{\circledR}$ Japan light microscope attached to a PM-10AK (Olympus Auto Exposure Control Unit PM-CBK-3) semi automatic photographic camera.

\section{Analysis procedures}

The histological evaluation applied a semi-quantitative method and was based on the presence of characteristics cells of the inflammatory process, kind of tissue in the implant-bone transition area, presence of fiberblasts (fibrosis), formation of fibrous pseudocapsule around the implanted material, trabecules of newly formed bone tissue (infiltration of bone tissue into the polymer), presence of osteoblasts, osteocytes and osteoclasts.

The variation magnitude between the variables and studied groups was carried out through Kruskal-Wallis test and when there was significant difference between the groups, the post hoc Student-Neuman-Keuls test was applied. The comparisons with $\mathrm{p}<0.05$ were considered as statistically significant. For data tabulation the Software Microsoft Office Excel 2007 was used and the statistic analysis was performed with the Bioestat 5.0 program.

The morphology of the castor polymer's surface added with calcium carbonate prior to implantation, with and without $\mathrm{SiO}_{2}$ nanoparticles, was evaluated through scanning electronic microscopy (SEM), in a JSM-6380LV Jeol Microscope, under $15 \mathrm{kV}$ typical tension acceleration.

\section{Results}

The results of the histological analysis of the various groups and periods studied are represented on Tables 1 to 3 .

In the animals from G1 - 15 days, it was observed the apposition of newly formed bone tissue in the margins of the bone defect with osteogenic activity inside the implanted material. At 30 days there was a larger amount of bone apposition in the margins and inside the defect invaginating towards the inner of the implant. The presence of osteocytes trapped in the gaps of the bone trabecules indicates the newly formed bone tissue maturing. After 60 days, a great area containing mature bone tissue was observed along with a larger quantity of osteocytes in the margins and in the interior of the defect, the osteoblastic activity was mantained and there was a great concentration of mature osteocytes (Figure 1). 


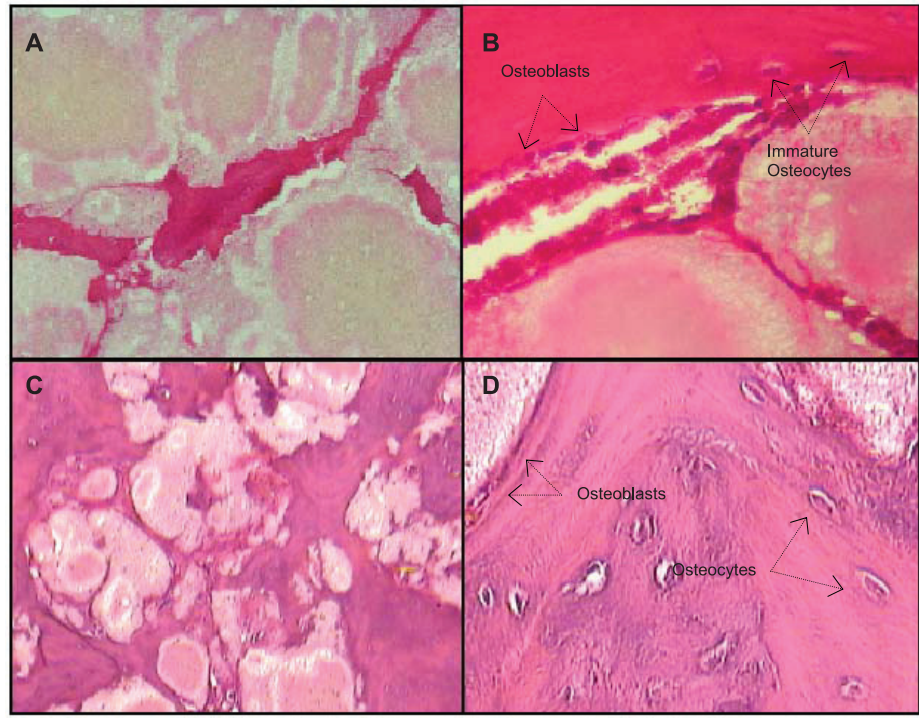

FIGURE 1 - Photomicrography from Group 1 animals. A (15 days): Newly formed bone tissue infiltrating through the polymer's pores. HE, 200X. B (30 days): Newly formed bone tissue maturing. HE, 400X. C and D (60 days): Bone neoformation and intense osteocitary paving. C - HE, 200X; D - HE, 400X.

TABLE 1 - Distribution of the variables averages obtained through the histological analysis $(n=03)-G 1$.

\begin{tabular}{cccccc}
\hline Pure polymer & $\mathbf{1 5}$ days & $\mathbf{3 0}$ days & $\mathbf{6 0}$ days & $\mathbf{P}$ & \\
\hline $\begin{array}{c}\text { Bone } \\
\text { Neoformation }\end{array}$ & $1.7 \pm 0.6$ & $2.7 \pm 0.6$ & $3.0 \pm 0.0$ & 0.056 & $\ldots$ \\
Fibroblasts & $1.0 \pm 1.0$ & $0.0 \pm 0.0$ & $1.0 \pm 0.0$ & 0.126 & $\ldots$ \\
Osteoblasts & $2.0 \pm 0.0$ & $2.0 \pm 1.0$ & $2.3 \pm 0.6$ & 0.739 & $\ldots$ \\
Osteocytes & $0.0 \pm 0.0$ & $1.0 \pm 1.0$ & $2.0 \pm 0.0$ & 0.065 & $\ldots$ \\
Osteoclasts & $1.0 \pm 1.0$ & $1.0 \pm 0.0$ & $1.0 \pm 0.0$ & 1.000 & $\ldots$ \\
\hline
\end{tabular}

In the animals from $\mathrm{G} 2$ - after 15 days, the presence of fibrous pseudocapsules, rich in fibroblasts and collagen fibers, was observed. After 30 days the absence of the fibrous pseudocapsule which involved the castor polymer and a progression of bone proliferation with isolated pores filling and fiber and bone tissue invasion to the interior of the polymer was observed. After 60 days some isolated pores were filled by bone with trabecular, immature aspect, with areas with higher bone deposition (Figure 2).

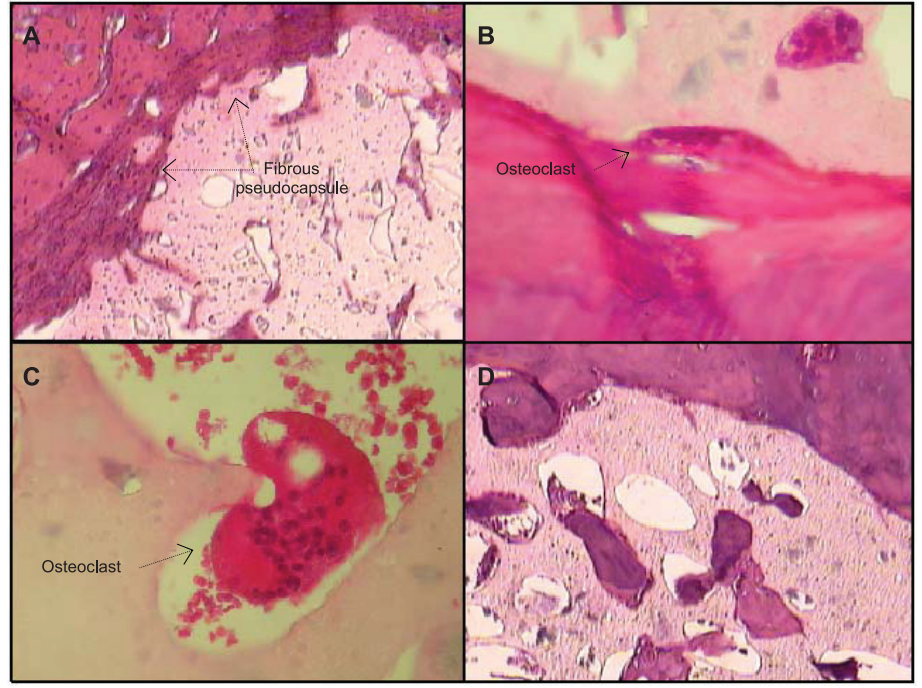

FIGURE 2 - Photomicrography montage from G2. A (15 days): fibrous pseudocapsule involving the castor polymer. HE,100X. B and C (30 days): multinucleated giant cell (osteoclast) eroding the biomaterial. HE, 400X. D (60 days): Filling and bone invasion to the interior of the material's isolated pores. HE, 400X.

TABLE 2 - Distribution of the variables averages obtained through the histological analysis $(n=03)-G 2$.

\begin{tabular}{cccccc}
\hline $\begin{array}{c}\text { Polymer: } \\
\mathbf{5 \%} \mathbf{S i O}_{2}\end{array}$ & $\mathbf{1 5}$ days & 30 days & $\mathbf{6 0}$ days & $\mathbf{P}$ & \\
\hline $\begin{array}{c}\text { Bone } \\
\text { Neoformation }\end{array}$ & $0.0 \pm 0.0$ & $2.0 \pm 0.0$ & $2.0 \pm 0,0$ & $0.022^{*}$ & $15 \mathrm{X} 30(0.04)$ \\
Fibroblasts & $3.0 \pm 0.0$ & $1.0 \pm 1.0$ & $1.0 \pm 0.0$ & $0.047^{*}$ & $15 \mathrm{X} 30(0.04)$ \\
& & & & & $15 \mathrm{X} 60(0.04)$ \\
Osteoblasts & $0.0 \pm 0.0$ & $1.0 \pm 0.0$ & $2.0 \pm 0.0$ & $0.021^{*}$ & $15 \mathrm{X} 60(0.01)$ \\
& & & & & \\
Osteocytes & $0.0 \pm 0.0$ & $1.0 \pm 1.0$ & $2.0 \pm 0.0$ & 0.122 & $\ldots$ \\
& & & & & \\
Osteoclasts & $0.0 \pm 0.0$ & $0.7 \pm 0.6$ & $1.3 \pm 0.6$ & 0.081 & $\ldots$ \\
\hline
\end{tabular}

In the G3 - after 15 days, it was possible to observe moderate bone growth into the implant, and a small fibroblastic activity producing the collagen matrix which precedes bone mineralization was observed. In the period of 30 days we observed more apposition of newly formed bone tissue in the edges of the bone defect with osteogenic activity also inside the implanted material. The continuous fibroblastic activity and the discreet deposition of collagen fibers on the receptor bed anticipate the bone neoformation/maturation. After 60 days we observed a larger presence of the osteoprogenitor cells with integrated activity of osteoblasts, osteocytes and osteoclasts operating the process of bone activation-reabsorption-formation. Only this group where the implant received $10 \%$ of silica nanoparticles presented 
osteoinductive properties (Figure 3).

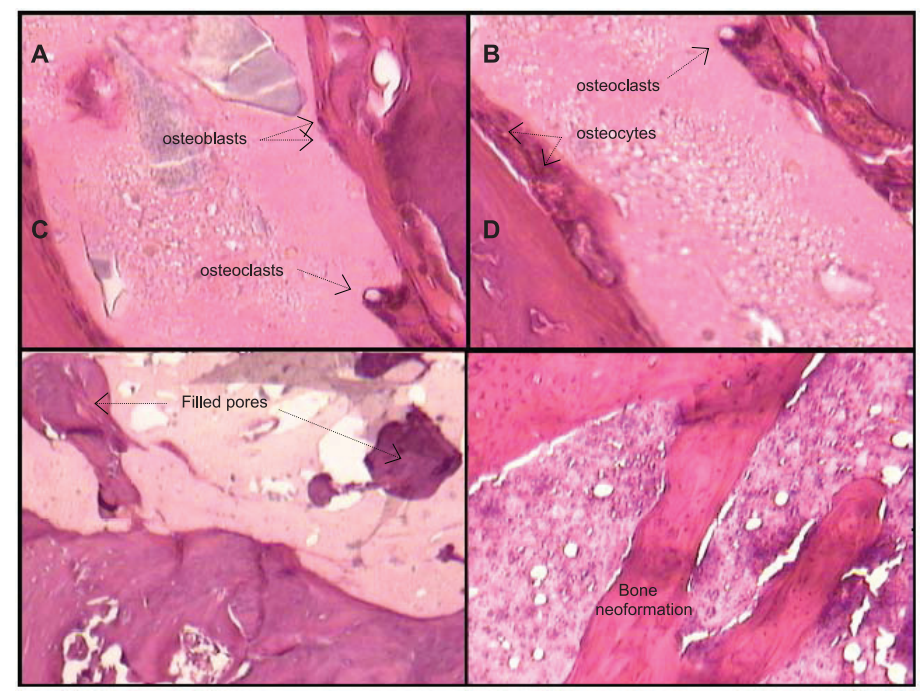

FIGURE 3 - Photomicrography montage from the G3. A and B (15 days): Cellular activity and the activation-reabsorption-formation of bone tissue over the polyurethane. HE, 400X. C (30 days): Pores filled with bone tissue .HE, 100X. D (60 days): Invasion of mature bone tissue into the polymer. HE, $100 \mathrm{X}$.

TABLE 3 - Distribution of the variables averages obtained through the histological analysis $(n=03)$ - G3.

\begin{tabular}{cccccc}
$\begin{array}{c}\text { Polymer: } \\
\mathbf{1 0 \%} \mathrm{SiO}_{2}\end{array}$ & $\mathbf{1 5}$ days & $\mathbf{3 0}$ days & $\mathbf{6 0}$ days & $\mathbf{P}$ & \\
$\begin{array}{c}\text { Bone } \\
\text { Neoformation }\end{array}$ & $1.0 \pm 0.0$ & $2.0 \pm 0.0$ & $2.3 \pm 0.6$ & $0.03^{*}$ & $\begin{array}{c}15 \mathrm{X} 60 \\
(0.02)\end{array}$ \\
& & & & & \\
Fibroblasts & $1.3 \pm 0.6$ & $1.3 \pm 0.6$ & $2.0 \pm 0.0$ & 0.201 & $\ldots$ \\
& & & & & \\
Osteoblasts & $1.0 \pm 1.0$ & $1.3 \pm 0.6$ & $3.0 \pm 0.0$ & 0.052 & $\ldots$ \\
& & & & & \\
Osteocytes & $0.3 \pm 0.6$ & $1.0 \pm 0.0$ & $2.3 \pm 0.6$ & $0.033^{*}$ & $\begin{array}{c}15 \mathrm{X} 60 \\
(0.01)\end{array}$ \\
& & & & & $15 \times 60$ \\
Osteoclasts & $0.7 \pm 0.6$ & $1.0 \pm 0.0$ & $2.0 \pm 0.0$ & $0.03 *$ & $(0.03)$ \\
\hline
\end{tabular}

\section{Discussion}

The presence of typical cells of the inflammatory process was observed in small quantity in all groups and analyzed periods with no significant statistic difference among them. The histological evaluation demonstrated that the bone neoformation occured gradually from the outside to the center of the cavity filled by the castor polymer in all the groups, and also that the implant materials influenced bone neoformation positively and the osteoconduction was the main way to bone regeneration.

According to Yoshikawa and Myoui ${ }^{8}$, the fundamental principle for the development of biomaterials used in bone tissue repair is the osteoconductive capacity with porous interconnection in combination with particles with osteogenic and osteoinductor potential. The osteoconductive biomaterial promotes bone tissue apposition in its surface working partly as a receptive receptacle which facilitates bone formation ${ }^{13}$. For Fukuda et al. ${ }^{9}$ and Albrektsson and Johansson ${ }^{14}$, the osteoconduction is a facilitation of the incursion of blood vessels and newly formed bone into a receptacle which should mainly provide a substratum in which osteoblastic cells can grow, differentiate and deposit extra cellular bone matrix.

The presence of fibrous conjunctive tissue around the implant forming a pseudocapsule which involved the material was evidenced in the G2 animals only in the initial evaluation period ( 15 days), which is a natural characteristic of this phase of regeneration. The dense conjunctive tissue found around the castor polymer in the initial observation periods should not be mistaken by that fibrous tissue responsible for isolating non biocompatible bodies. The main difference between these two tissues lies in their morphologies. The fibrous capsule is exclusively constituted by collagen fibers, whereas the dense conjunctive tissue, similar to the one found in this study, has in its composition both collagen fibers and a great cell population, which can afterwards differentiate into osteoprogenitor cells ${ }^{15,16}$. The presence of fibrous conjunctive tissue in the bone-polymer interface, with or without regions establishing direct contact of the bone tissue with the implant could also be observed in various studies by many authors ${ }^{17,18}$.

According to Beloti et al. ${ }^{4}$ and Laureano Filho et al. ${ }^{5}$, the fibrous connective tissue which surrounded the material were in maturation process, gradually altering their structural form to organic bone matrix lamels, with abundant osteoblasts and newly formed bone trabecules which filled the polyurethane porosities.

In our study the presence of osteogenic cells was predominantly bigger in the animals which received the castor polymer implant containing $10 \%$ silica. During all the evaluated periods it was possible to observe a higher number of fibroblasts, osteobalsts, osteocytes and osteoclasts around and inside the implant when compared to the other groups. Silica plays a fundamental role in certain bioactive glasses, it is capable of osteoprogenitor cells induction in the lesion area ${ }^{10,19}$. The success of the castor polymer containing $10 \%$ silica may be attributed to the fact that silica, beyond the inductive properties, can promote great roughness, observed through the SEM. 
SEM analysis of group 1 showed quite rough, irregular surface, with saliencies and reentrancys which suggest that the bone tissue adhesion and growth depend on the surface's roughness. The surface of the implant doped with $10 \%$ silica presented protuberances and furrows of different sizes, which in association to the ceramics's osteoinductive capacity may have favored cell aggregation and bone neoformation in the boneimplant interface (Figure 4).

Moreover, the porosity in surface of the polymeric supports can modulate the cellular adhesion and proliferation taxes, because the pores represent an increase in the contact surface with the cells and yet, serve as an artificial temporary matrix until the cells synthesize their own ${ }^{20}$.

(a)

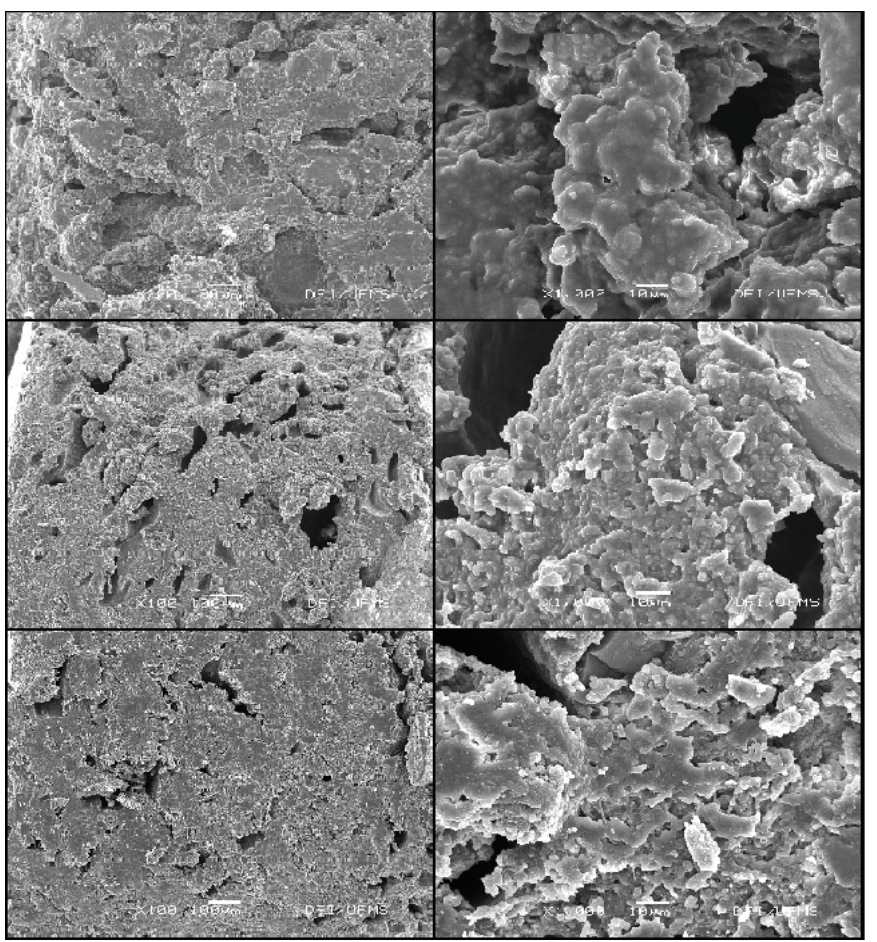

FIGURE 4 - SEM of the castor polymer before implant. (a) - Castor polymer without doping. (b) - Castor polymer with $5 \% \mathrm{SiO}_{2}$. (c) - Castor polymer with $10 \% \mathrm{SiO}_{2}$.

\section{Conclusions}

The castor polymer in association with silica nanoparticles as filling material for bone defect was biocompatible, behaving as a receptive frame which facilitates bone neoformation and it was capable of promoting osteoprogenitor cells induction.

\section{References}

1. Camargo SE, Rode SM, do Prado RF, Carvalho YR, Camargo $\mathrm{CH}$. Subcutaneous tissue reaction to castor oil bean and calcium hydroxide in rats. J Appl Oral Sci. 2010;18(3):273-8.

2. Frazilio FO, Rossi R, Negrini Neto JM, Facco GG, Ovando TM, Fialho MPF. Use of castor oil polyurethane in an alternative technique for medial patella surgical correction in dogs. Acta Cir Bras. 2006;21(4):74-9.

3. Laureano Filho JR, Branco BLC, Andrade ESS, Barbosa JRA. Histological comparison of demineralized bone matrix and the Ricinus communis polymer on bone regeneration. Braz J Otorhinolaryngol. 2007;73(2):186-92.

4. Beloti MM, Oliveira PT, Tagliani MM, Rosa AL. Bone cell responses to the composite of Ricinus communis polyurethane and alkaline phosphatase. J Biomed Mater Res A. 2008;84:435-41.

5. Laureano Filho JR, Andrade ES, Albergaria-Barbosa JR, Camargo IB, Garcia RR. Effects of demineralized bone matrix and a 'Ricinus communis' polymer on bone regeneration: a histological study in rabbit calvaria. J Oral Sci. 2009;51(3):451-6.

6. Barros VM, RosaAL, Beloti MM, Chierice G. In vivo biocompatibility of three different chemical compositions of Riccinus communis polyurethane. J Biomed Mater Res A. 2003;67:235-9.

7. Campos SD, Campos EA, Silveira CB, Bini RA. Biomateriais à base de $\mathrm{Na} 2 \mathrm{O}-\mathrm{CaO}-\mathrm{SiO} 2-\mathrm{P} 2 \mathrm{O} 5$ preparados com serragem e com glucose de milho: influência na porosidade e na cristalinidade. Cerâmica. 2005;51(319):274-9.

8. Yoshikawa $\mathrm{H}$, Myoui A. Bone tissue engineering with porous hydroxyapatite ceramics. J Artif Organs. 2005;8:131-6.

9. Fukuda A, Takemoto M, Saito T, Fujibayashi S, Neo M, Pattanayak DK, Matsushita T, Sasaki K, Nishida N, Kokubo T, Nakamura $\mathrm{T}$. Osteoinduction of porous Ti implants with a channel structure fabricated by selective laser melting. Acta Biomater. 2011;7(5):232736.

10. Ohtsuki C, Kamitakahara M, Miyazaki T. Bioactive ceramic-based materials with designed reactivity for bone tissue regeneration. J R Soc Interface 2009;6 Suppl 3:S349-60.

11. Tabatabaei S, Shukohfar A, Aghababazadeh R, Mirhabibi A. Experimental study of the synthesis and characterisation of silica nanoparticles via the sol-gel method. J Physics Conference Series. 2006;26:371-4.

12. Lee JH, Lee CK, Chang BS, Ryu HS, Seo JH, Hong KS, Kim H. In vivo study of novel biodegradable and osteoconductive $\mathrm{CaO}-\mathrm{SiO}_{2}-$ $\mathrm{B}_{2} \mathrm{O}_{3}$ glass-ceramics. J Biomed Mater Res A. 2006;77(2):362-9.

13. Bauer TW, Smith ST. Bioactive materials in orthopaedic surgery: overview and regulatory considerations. Clin Orthop Relat Res. 2002;395:11-22.

14. Albrektsson T, Johansson C. Osteoinduction, osteoconduction and osseointegration. Eur Spine J. 2001;10:96-101.

15. Leite FRM, Ramalho LTO. Bone regeneration after demineralized bone matrix and castor oil (ricinus communis) polyurethane implantation. J Appl Oral Sci. 2008;16(2):122-6.

16. Leonel ECF, Andrade Sobrinho J, Oliveira Ramalho LT, Porciúna HF, Mangilli R. The action of the castor bean polymer during the bone neoformation. Acta Cir Bras. 2004;19(4):342-50.

17. Pereira-Júnior OC, Rahal SC, Iamaguti P, Felisbino SL, Pavan PT, Vulcano LC. Comparison between polyurethanes containing castor oil (soft segment) and cancellous bone autograft in the treatment of segmental bone defect induced in rabbits. J Biomater Appl. 2007;21(3):283-97.

18. Boeck-Neto RJ, Gabrielli MF, Shibli JÁ, Marcantonio E, Lia RC, Marcantonio E. Histomorphometric evaluation of human sinus floor augmentation healing responses to placement of calcium phosphate 
or Ricinus communis polymer associated with autogenous bone. Clin Implant Dent Relat Res. 2005;7(4):181-8.

19. Borum L, Wilson Jr OC. Surface modification of hydroxyapatite. Part II. Silica. Biomaterials. 2003;24(21):3681-8.

20. Köse GT, Ber S, Korkusuz F, Hasirci V. Poly (3-hydroxybutyric acid-co-3-hydroxyvaleric acid) based tissue engineering matrices. J Mater Sci Mater Med. 2003;14(2):121-6.

\section{Correspondence:}

Renato Silva Nacer

Travessa João Domingos, 231/casa 04

79050-032 Campo Grande-MS Brasil

Tel.: (55 67)9207-5182

renatosnacer@gmail.com

Received: August 23, 2011

Review: October 20, 2011

Accepted: November 21, 2011

Conflict of interest: none

Financial source: none

${ }^{1}$ Research performed at the Postgraduate Program in Health and Development in the West Central Region, Federal University of Mato Grosso do Sul (UFMS), Campo Grande-MS, Brazil. Part of the dissertation of the first author. 